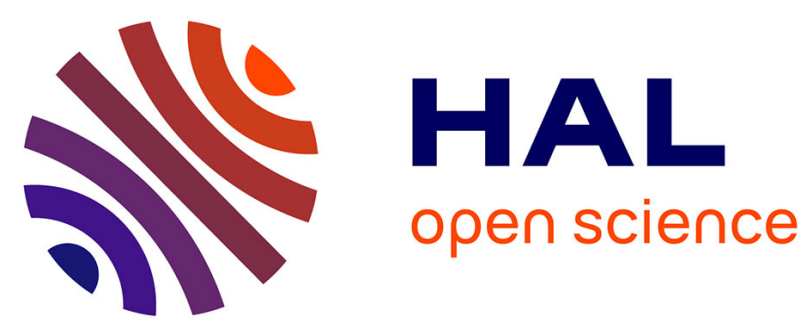

\title{
Cellular interactions of functionalized superparamagnetic iron oxide nanoparticles on oligodendrocytes without detrimental side effects: Cell death induction, oxidative stress and inflammation
}

S. Sruthi, Lionel Maurizi, T. Nury, F. Sallem, J. Boudon, J. Riedinger, N. Millot, F. Bouyer, G. Lizard

\section{To cite this version:}

S. Sruthi, Lionel Maurizi, T. Nury, F. Sallem, J. Boudon, et al.. Cellular interactions of functionalized superparamagnetic iron oxide nanoparticles on oligodendrocytes without detrimental side effects: Cell death induction, oxidative stress and inflammation. Colloids and Surfaces B: Biointerfaces, 2018, 170, pp.454-462. 10.1016/j.colsurfb.2018.06.041 . hal-02163524

\section{HAL Id: hal-02163524 \\ https://hal.science/hal-02163524}

Submitted on 8 Mar 2021

HAL is a multi-disciplinary open access archive for the deposit and dissemination of scientific research documents, whether they are published or not. The documents may come from teaching and research institutions in France or abroad, or from public or private research centers.
L'archive ouverte pluridisciplinaire HAL, est destinée au dépôt et à la diffusion de documents scientifiques de niveau recherche, publiés ou non, émanant des établissements d'enseignement et de recherche français ou étrangers, des laboratoires publics ou privés. 


\title{
Cellular interactions of functionalized superparamagnetic iron oxide nanoparticles on oligodendrocytes without detrimental side effects: cell death induction, oxidative stress and inflammation
}

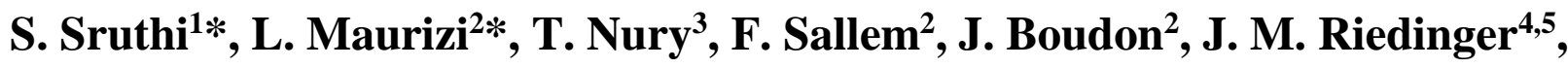 \\ N. Millot ${ }^{2}$, F. Bouyer ${ }^{2}$, G. Lizard ${ }^{3}$ \\ * Both authors share first authorship
}

1: Toxicology Division, Biomedical Technology Wing, Sree Chitra Tirunal Institute for Medical Sciences and Technology, Thiruvananthapuram, 695 012, Kerala, India

2: Laboratoire Interdisciplinaire Carnot de Bourgogne, UMR 6303, CNRS, Université Bourgogne Franche-Comté, BP 47870, 21078 Dijon Cedex, France

3: University Bourgogne Franche-Comté, Lab. Bio-PeroxIL, 'Biochemistry of the Peroxisome, Inflammation and Lipid Metabolism' (EA7270) / Inserm, Dijon, France

4: Department of Nuclear Medicine, Centre GF Leclerc, Dijon

5: Departments of Biology and Pathology, Centre GF Leclerc, Dijon, France

Corresponding authors L Maurizi (Chemistry of nanoparticles: lionelmaurizi@ gmail.com); G. Lizard (Cell biology and toxicology: Gerard.Lizard@u-bourgogne.fr)

\section{Statistical Summary:}

Abstract:

238 words

Main manuscript:

7 Figures

5945 words (including figures captions) 


\begin{abstract}
Iron oxide nanoparticles have the capability to cross Blood Brain Barrier (BBB) and hence are widely investigated for biomedical operations in the central nervous system. Before being used in humans, it is necessary to investigate their biocompatibility, dosimetry and biological interaction. In the present study, in-house synthesized superparamagnetic iron oxide nanoparticles (SPIONs) were functionalized using the polymer, PolyEthylene Glycol and a fluorophore (Rhodamine) (fSPIONs). The interaction of fSPIONs with murine oligodendrocytes $158 \mathrm{~N}$ revealed that the nanoparticles were taken up by the cells via endocytosis, and there was a dose-dependent increase in the intracellular iron content as revealed by flow cytometry, transmission electron microscopy and confocal microscopy. Nanoparticles remained stable inside the cells even after $24 \mathrm{~h}$. In addition, interaction and/or accumulation of nanoparticles was supported by the possibility to isolate treated cells even after $24 \mathrm{~h}$. Cell sorting capacity using a magnet depended on the amount of particles . Noteworthy, whereas these nanoparticles can interact per cell. fSPIONs exhibited good biocompatibility as no toxicological response, including morphological changes, loss of viability, oxidative stress or inflammatory response (IL-1 $\beta$, IL-6 secretion) was observed. These data show that the in-house synthesized fSPIONs have no accumulate on $158 \mathrm{~N}$ oligodendrocytes without the side effects on $158 \mathrm{~N}$ cells, and constitute interesting tools for biomedical applications on nerve cells, including cellular imaging and targeting (oxidative stress, inflammation and cell death) that could be detrimental when a subsequent use of these nanoparticles in humans is considered.
\end{abstract}

\title{
Introduction
}

Currently, superparamagnetic iron oxide nanoparticles (SPIONs) are one of the most researched and successfully developed nanoparticles regarding biomedical operations. They possess a high magnetic moment, a high surface to volume ratio and a magnetic hysteresis [1]. These unique properties make them ideal for use as magnetic resonance imaging (MRI) contrast agents [2,3], for gene and drug delivery applications, in cell imaging, in hyperthermia [4] and as nano-sensors [5]. Other applications of magnetic nanoparticles include cell targeting and cell sorting [6,7]. SPIONsbased products like Ferucarbotran are commercially available as MRI contrast agent [8]. 
From a biomedical perspective, nanoparticle functionalization aims at designing novel therapeutic modalities with increased efficacy. These functionalization results in better stability, biocompatibility, improved particodynamics and kinetics. The cellular interactions of nanoparticles are deeply influenced by their physicochemical properties [9]. Parameters such as particle size, morphology, surface charge, crystallinity, coating, etc. are important with regard to bio-nano interactions [10]. Polyethylene glycol (PEG) is a polymer commonly used to increase the biocompatibility of SPIONs as well as to aid in further molecular conjugation [10,11]. When it comes to developing a drug carrier, fluorophores conjugation comes handy. Functionalization of nanoparticle with a fluorophore proves as a feasible strategy in testing the efficacy of the nanodrug carriers instead of using the actual drug. This functionalization ensures the nanoparticle monitoring inside the cells, tissues or any other area of interest $[12,13]$. These probes can also give information about the nanoparticles loading efficiency, cellular retention and their possible degradation inside cells. In addition to these, the fluorescent probe-conjugated magnetic nanoparticles provide information on the intracellular distribution of nanoparticles, especially on their localization in different cell compartments [14] and their interaction with organelles playing key roles in cell metabolism, cell function and cell viability [15].

The iron localization and subsequent induction of reactive oxygen species (ROS) has been linked with neurodegeneration [16]. It has been reported that the SPIONs can cross the blood brain barrier (BBB) in presence of an external magnetic field and a number of application has been envisaged based on this discovery. For the same reason it is equally important to test the neurotoxic potential of these nanoparticles to avoid unanticipated outcomes. In the central nervous system (brain + spinal cord) oligodentrocytes are the principle cells to accumulate iron under normal conditions [17]. The oligodendrocytes produce the myelin sheath which wraps the axon and permits an efficient conduction of the nervous influx [18]. They act as major store house of iron in the brain [16] and there for is highly susceptible to ROS mediated myelin degeneration [19]. Iron mismanagement and iron mediated ROS generation in oligodendrocytes may have a huge impact on other cells of the brain through intercellular translocation [20]. Hence studying oligodendrocytes would help in better understanding of the neurotoxic potential of SPIONs.

Based on numerous in vitro studies, $158 \mathrm{~N}$ cells are considered as a good model to determine the influence of environmental factors on oxidative stress, inflammation and cell death induction [21]. 
The $158 \mathrm{~N}$ cells is obtained by immortalization of oligodendrocytes from normal mice with the Simian Virus 40 (SV-40) large $\mathrm{T}$ antigen. They exhibit phenotype similar to that of welldifferentiated oligodendrocytes in their ability to synthesize major myelin proteins [22,23]. As cytotoxic effects on oligodendrocytes can have dramatic consequences on brain functions, $158 \mathrm{~N}$ cells were used in the present study to precise the impact of SPIONs interaction with oligodendrocyte cells.

The toxicological interaction of SPIONs with oligodentrocytes has been reported previously with data contradicting the hypothesis of SPION mediated ROS production in oligodentrocytes [24,25]. However, Present study aimed at designing a biocompatible theranostic modality by functionalizing SPIONs with the polymer, silanated methoxy-polyethylene glycol (mPEG-Si) of 2000 g.mol-1 and a Rhodamine fluorophore (RITC). This complete functionalized SPIONs are designated as fSPIONs throughout the manuscript. The cellular interactions and biocompatibility of the fSPIONs with the murine oligodendrocyte $158 \mathrm{~N}$ cells were assessed, prior to exploiting these particles for targeted drug delivery across brain. Parameters like fluorescence, magnetic separation potential, cell viability oxidative stress and inflammation were evaluated for the preliminary understanding of the application potential and toxicity. This study gives an idea about the dosimetry of fSPIONs for drug delivery application.

\section{Materials and methods}

\section{Synthesis and functionalization of SPIONs}

\section{Nanoparticles preparation}

Naked superparamagnetic iron oxide nanoparticles (SPIONs) were synthesized following a coprecipitation protocol [4]. Briefly a stoichiometric mixture of $20 \mathrm{~mL}$ of a $2 \mathrm{M}$ iron II chloride solution and $80 \mathrm{~mL}$ of a $1 \mathrm{M}$ iron III chloride solution (molar ratio $\mathrm{Fe}^{\mathrm{II}}: \mathrm{Fe}^{\mathrm{III}}=1: 2$ ) was added dropwise to $800 \mathrm{~mL}$ of $0.75 \mathrm{M} \mathrm{NaOH}$ solution $\left(25^{\circ} \mathrm{C}\right)$. The basic SPIONs suspension was then washed and peptized 7 times with a $1 \mathrm{M} \mathrm{HNO}_{3}$ solution. The suspension was dialyzed for $24 \mathrm{~h}$ against a $\mathrm{pH} 3 \mathrm{HNO}_{3}$ solution. The suspension was centrifuged at $5000 \times \mathrm{g}$ for $15 \mathrm{~min}$ and only the supernatant was kept. The final SPIONs concentration is $23 \mathrm{mg}$ of nanoparticles per $\mathrm{mL}$. 


\section{Nanoparticles functionalization}

Methoxy-polyethylene glycol of 2000g. $\mathrm{mol}^{-1}\left(\mathrm{mPEG}_{2000}\right)$ and rhodamine B isothiocyanate (RITC) were silanized with the coupling of ICPTS [26] and APTES respectively in dried THF at $60^{\circ} \mathrm{C}$ under nitrogen flow for $48 \mathrm{~h}$. Dibutyltindilaurate was used as a catalyst for the reaction of silanized mPEG ( $\left.\mathrm{mPEG}_{2000}-\mathrm{Si}\right)$ and the polymers were precipitated in hexane and dried. The rhodaminesilane (RITC-Si) was redispersed in ethanol and stored at $-20^{\circ} \mathrm{C}$. Functionalized SPIONs were obtained following this protocol. $0.13 \mathrm{mmol}$ of $\mathrm{mPEG}_{2000}-\mathrm{Si}$ were dissolved in $40 \mathrm{~mL}$ ethanol/water (50/50: v/v [11]) at $\mathrm{pH} 4$ and $25^{\circ} \mathrm{C}$. $100 \mathrm{mg}$ of SPIONs and $5 \mu$ moles of RITC-Si were added and the reaction occurs during $48 \mathrm{~h}$ under nitrogen and protected from light. The suspensions were then dialyzed against water for one week (cellulose dialysis membranes with cutoff of $12-14 \mathrm{kDa}$ ). The complete functionalized particles will be referred to as fSPIONs throughout this paper. All the reagents and the methods to characterize the SPIONs and fSPIONs are given in supplementary material.

\section{Cell culture}

Murine oligodendrocytes $158 \mathrm{~N}$ cells were cultured in Dulbecco's modified Eagle's medium supplemented with $10 \%(\mathrm{v} / \mathrm{v})$ heat inactivated fetal bovine serum (PANTM Biotech GmbH, Aidenbach, Germany) and 1\% antibiotic (Penicillin, Streptomycin) solution ((PANTM Biotech $\mathrm{GmbH})$. The cells were cultured either in Petri dishes (100 mm in diameter) or in six, twelve or twenty-four-well plates depending on the experiment realized $\left(30,000\right.$ cells $/ \mathrm{cm}^{2} ; 2,1$ and $0.5 \mathrm{~mL}$ of culture medium in six, twelve or twenty-four-well plates, respectively). The culture flasks were maintained at $37^{\circ} \mathrm{C}$ in a humidified atmosphere containing $5 \% \mathrm{CO}_{2}$. For subcultures, cells were trypsinized (0.05\% trypsin-0.02\% EDTA solution) and passaged twice a week. Cells at $70-80 \%$ confluency (previously cultured for $24 \mathrm{~h}$ ) were incubated with fSPIONs for different duration (2, 4, 6 and $24 \mathrm{~h}$ ). The concentrations of the particles used for the experiments were 1, 5, 10, 50 and/or $100 \mu \mathrm{g}_{\mathrm{Fe}} / \mathrm{mL}$.

\section{Cell morphology}

\section{Phase contrast Microscopy}


Effect of fSPIONs on cell morphology was analyzed using phase contrast microscopy. Cells were seeded in $24-w e l l$ plates. After $24 \mathrm{~h}$ of culture (70-80\% of confluency), cells were incubated with $1,5,10,50$ and $100 \mu \mathrm{g}_{\mathrm{Fe}} / \mathrm{mL}$ of fSPIONs for $6 \mathrm{~h}$. The wells were observed under an invertedphase contrast microscope (Axiovert 40 CFL, Zeiss, Jena, Germany). Digitalized images were obtained with a camera (Axiocam ICm1, Zeiss).

\section{Evaluation of the internalization of fSPIONs by murine oligodendrocytes $158 \mathrm{~N}$}

\section{Measurement of light scatters by flow cytometry}

The forward scatter (FSC) and the side scatter (SSC) have been reported to be modified in the presence of some nanoparticles [27]. It was therefore of interest to evaluate whether these parameters can be used to estimate the interaction and/or internalization of fSPIONs with $158 \mathrm{~N}$ cells. To this end, the cells were seeded in 6-well plates. After $24 \mathrm{~h}$ of culture $(70-80 \%$ of confluency), cells have been exposed to nanoparticles concentrations of 1, 5, 10, 50 and $100 \mu \mathrm{g}_{\mathrm{Fe}} / \mathrm{mL}$ for $6 \mathrm{~h}$. The cells, harvested by trypsinization ( $0.05 \%$ trypsin- $0.02 \%$ EDTA solution) and centrifugation $(900 \times \mathrm{g}, 10 \mathrm{~min})$ were re-suspended in Phosphate Buffer Saline (PBS) and immediately analyzed by flow cytometry on a Galaxy flow cytometer (Partec, Münster, Germany). For each assay, 10,000 cells were analyzed and the mean value of FCS and SSC were measured on a logarithmic scale of fluorescence.

Flow cytometric measurement of fSPIONs- interaction and/or internalization: measurement of RITC-associated mean fluorescence intensity (MFI)

The interaction and/or internalization of fSPIONs (1, 5, 10, 50 and $\left.100 \mu \mathrm{g}_{\mathrm{Fe}} / \mathrm{mL} ; 6 \mathrm{~h}\right)$ with $158 \mathrm{~N}$ cells was measured by flow cytometry. For this purpose, at the end of the treatment, cells were detached by trypsinization, re-suspended in PBS and analyzed by flow cytometry with a Facscanto 10 (Becton-Dickinson, NJ, USA) at a laser excitation of $514 \mathrm{~nm}$. The red fluorescence of RITC was collected on 10,000 cells and the MFI was measured on a logarithmic scale. 


\section{Transmission electron microscopy (TEM)}

The murine oligodendrocyte $158 \mathrm{~N}$ cells were exposed to fSPIONs $\left(50 \mu \mathrm{g}_{\mathrm{Fe}} / \mathrm{mL}\right)$ for $6 \mathrm{~h}$. For TEM observation cell samples were prepared as previously described [28]. After trypsination and washing in PBS, the cell samples were fixed for $1 \mathrm{~h}$ at $4{ }^{\circ} \mathrm{C}$ in $2.5 \%(\mathrm{w} / \mathrm{v})$ glutaraldehyde diluted in cacodylate buffer (0.1 M, pH 7.4), washed twice in cacodylate buffer (0.1 M, pH 7.4), post-fixed in $1 \%(\mathrm{w} / \mathrm{v})$ osmium tetroxide diluted in cacodylate sodium $(0.1 \mathrm{M}, \mathrm{pH} 7.4)$ for $1 \mathrm{~h}$ at $25^{\circ} \mathrm{C}$ in the dark, and rinsed twice with cacodylate buffer $(0.1 \mathrm{M}, \mathrm{pH}$ 7.4). The preparations were then dehydrated in graded ethanol solutions and embedded in Epon. Ultra-thin sections were cut with a diamond knife on an ultramicrotome, contrasted with uranyl acetate and lead citrate, and examined using an H7500 electron microscope (Hitachi, Tokyo, Japan).

\section{Confocal microscopy}

The cells were seeded in a 24-well plate and allowed to attach overnight on glass coverslips. They have been incubated with particles $\left(1,5,10,50\right.$ and $\left.100 \mu \mathrm{g}_{\mathrm{Fe}} / \mathrm{mL}\right)$ for $24 \mathrm{~h}$. The nuclei were counterstained with Hoechst $33342(1 \mu \mathrm{g} / \mathrm{mL})$. The slides were previously observed under an Axioskop (Zeiss) using green excitation [29]. Confocal microscopy was realized on a Confocal Laser Scanning Microscope Leica SP2 AOBS (Leica Microsystems, Mannheim, Germany). Cells were excited in UV and with blue light to visualize the nuclei and fSPIONs, respectively. The excitation emission conditions were the following: Hoechst 33342 ( $\lambda$ excitation/emission: $346 / 461 \mathrm{~nm}$ ); RITC ( $\lambda$ excitation/emission: $514 / 575 \mathrm{~nm}$ ). Images obtained by confocal microscopy are stacked images resulting from the acquisition of images in different planes with a depth of $0.29 \mu \mathrm{m}$. The depth of analysis was around $10 \mu \mathrm{m}$ leading to 35 planes per acquisition.

\section{Perls staining}

Cells treated with fSPIONs $\left(1,5,10,50\right.$ and $\left.100 \mu \mathrm{g}_{\mathrm{Fe}} / \mathrm{mL} ; 24 \mathrm{~h}\right)$ were first washed in PBS. Then, cell deposits of around 40000 cells were carried out on glass slides with a cytospin (Shandon, Sheshire, UK). After fixation in $5 \%$ paraformaldehyde $(10 \mathrm{~min})$, cells were stained with a $5 \%$ potassium ferrocyanide / 5\% hydrochloric acid solution diluted in distilled water (30 min). After 
washing in distilled water the resulting Prussian blue stain can be observed, and the nuclei were counterstained with hematoxylin. This method of coloration is commonly used to detect iron accumulation inside cells (iron accumulation appears as blue dots of various size and shapes, and the nuclei are colored in dark pink). The method was used to detect fSPIONs in $158 \mathrm{~N}$ cells by brightfield microscopy under a right microscope (Axio-Skope A1, Zeiss). Digitalized images were obtained with an Axiocam camera (Zeiss).

\section{Induced Coupled Plasma Spectroscopy (ICP)}

Cells were incubated with $0,1,10,100 \mu \mathrm{g}_{\mathrm{Fe}} / \mathrm{mL}$ of fSPIONs for $6 \mathrm{~h}$. Then the cells were dissolved in $\mathrm{HNO}_{3}(69 \%)$ before being diluted twice and analyzed by Induced Coupled Plasma spectroscopy (ICP iCAP 7400).

\section{Cell sorting}

Cultured $158 \mathrm{~N}$ cells were incubated with fSPIONs $\left(50 \mu \mathrm{g}_{\mathrm{Fe}} / \mathrm{mL}\right)$ for $24 \mathrm{~h}$. Then, cells were trypsinized, re-suspended in PBS, and submitted to a magnetic field with a magnet (EasySep, StemCell Technologies, Grenoble, France). The cells that remain in the supernatant (cells nonretained by the magnet meaning cells without fSPIONs or associated with low levels of fSPIONs as determined by Perls staining) and those in the pellet (cells retained by the magnet and associated with fSPIONs as determined by Perls staining) were collected, re-suspended in PBS and numerated on cell deposits realized with a cytospin (Shandon, Cheshire, UK).

\section{Cell viability}

\section{Trypan blue staining}

Cell viability was assessed by trypan blue exclusion assay: trypan blue is excluded by viable cells and stains dead cells blue [30]. In this condition, cells were cultured in 6-well plates (70,000 cells / well in $2 \mathrm{~mL}$ of culture medium). This method allows to determine the percentage 
of viable and dead cells, and also to evaluate cell growth. The culture was exposed to fSPIONs $\left(50 \mu \mathrm{g}_{\mathrm{Fe}} / \mathrm{mL}\right)$ for $2,4,6$, and $24 \mathrm{~h}$. The $158 \mathrm{~N}$ cells were harvested by trypsinization and centrifugation. The resulting pellets were re-suspended in PBS. The cell suspension was mixed with trypan blue $(\mathrm{v} / \mathrm{v})$ and counted using a Malassez cell count.

\section{Sytox Green staining}

As the used fSPIONs emit a red fluorescence, Sytox Green staining was used to quantify dead cells. Staining with Sytox Green and flow cytometric analysis were realized as previously described [31]. Briefly, $158 \mathrm{~N}$ cells were previously cultured for $24 \mathrm{~h}$; then, they were incubated fSPIONs at $100 \mu \mathrm{g}_{\mathrm{Fe}} / \mathrm{mL}$ for 2, 4 and $6 \mathrm{~h}$.[31]. After washing with PBS, cells were stained with a $500 \mathrm{nM}$ Sytox Green solution ( $\lambda$ excitation: $504 \mathrm{~nm}$; $\lambda$ emission: $523 \mathrm{~nm}$ ) and incubated for 10 minutes in the dark. Cells fluorescence was finally analyzed by flow cytometry using a Partec flow cytometer (laser excitation: $488 \mathrm{~nm}$ ), and the green fluorescence of Sytox Green was collected through a 525/10 nm band pass filter. For each assay, about 10,000 cells were analyzed and the percentage of Sytox Green positive cells (dead cells) was determined on a logarithmic scale.

\section{Evaluation of oxidative stress}

\section{Flow cytometric measurement of reactive oxygen species (ROS) production}

To estimate the production of reactive oxygen species (ROS), $\mathrm{H}_{2}$ DCF-DA test was used [32]. After incubation with fSPIONs (100 $\mu \mathrm{g}_{\mathrm{Fe}} / \mathrm{mL}$ at 2,4 and $\left.6 \mathrm{~h}\right), 158 \mathrm{~N}$ cells were trypsinized; cells $\left(5 \times 10^{5}\right.$ cells $/ \mathrm{mL}$ of culture medium) were then incubated for $1 \mathrm{~h}$ at $37^{\circ} \mathrm{C}$ in the dark with $10 \mu \mathrm{mol} / \mathrm{L}$ of $\mathrm{H}_{2}$ DCF-DA (2',7'-Dichlorodihydrofluorescein diacetate: Thermo Fisher Scientific). The 2',7'dichlorofluorescein (DCF) fluorescence resulting from the oxidation of $\mathrm{H}_{2}$ DCF-DA was measured for about 10,000 cells on a logarithmic scale of fluorescence by using a Galaxy flow cytometer (Partec, Münster) at excitation and emission wavelengths of $488 \mathrm{~nm}$ and 525/10 nm, respectively. 
The level of reduced glutathione (GSH) was determined on cells treated with fSPIONs (50 and $\left.100 \mu \mathrm{g}_{\mathrm{Fe}} / \mathrm{mL}, 6 \mathrm{~h}\right)$, as well as on untreated cells used as negative control and on diamide (0.5 mM)treated cells, taken as positive control. At the end of the treatment, $158 \mathrm{~N}$ cells were harvested by trypsinization and centrifuged at $700 \times \mathrm{g}$ for 5 minutes. The level of GSH was determined after staining with monochlorobimane as previously described [32]. Monochlorobimane was excited at $360 / 370 \mathrm{~nm}$ with a 75W mercury/xenon lamp and the fluorescence was collected with a 450/20 nm band pass filter. The mean fluorescence intensity of monochlorobimane positive cells was determined on a Galaxy flow cytometer (Partec, Münster). For each assay, 10,000 cells were analyzed and the corresponding mean fluorescence intensity of monochlorobimane was determined on a logarithmic scale of fluorescence.

\section{Evaluation of inflammation}

The inflammatory response was evaluated by the secretion of the interleukines IL-1 $\beta$ and IL-6 (two pro-inflammatory cytokines), measured in the culture medium using an enzyme-linked immunosorbent assay (ELISA) test: mouse Interleukin-1 $\beta$ kit and mouse Interleukin-6 kit (eBioscience Inc. / CliniSciences, Nanterre, France). To this end, $158 \mathrm{~N}$ cells (previously cultured for $24 \mathrm{~h}$ to reach $70-80 \%$ of confluency) were cultured with fSPIONs at $100 \mu \mathrm{g}_{\mathrm{Fe}} / \mathrm{mL}$ for $2,4,6$ and $24 \mathrm{~h}$; untreated cells were used to determine the basal level of IL-1 $\beta$ and IL- 6 in the culture medium. At the end of the treatment, the culture medium was collected and centrifuged in order to eliminate cells. Based on the manufacturer recommendations, the ELISA plates were coated with the appropriated capture antibodies overnight at $4{ }^{\circ} \mathrm{C}$ and the incubation with the different culture media were realized for $1 \mathrm{~h}$ at $21^{\circ} \mathrm{C}$. Then $100 \mu \mathrm{L}$ of avidine-HRP were added and the plates were kept at $21{ }^{\circ} \mathrm{C}$ for 30 minutes. $100 \mu \mathrm{L}$ of Tetramethylbenzidine (TMB) substrate was added for 15 minutes, and $50 \mu \mathrm{L}$ of $\mathrm{H}_{2} \mathrm{SO}_{4}(4 \mathrm{M})$ was added to stop the colorimetric reaction. The optical densities of ELISA plates were read at $450 \mathrm{~nm}$. The concentrations of IL-1 $\beta$ and IL- 6 were determined using calibration curves.

\section{Statistical analyses}


The experimental data represent the mean \pm standard deviation. Statistical analyses were performed using SigmaStat 2.03 software (Systat Software) with the Mann-Whitney test. Data were considered statistically different at a $P$-value of 0.05 .

\section{Results}

\section{Characterization of nanoparticles}

The physico-chemical properties of the naked and functionalized SPIONs are summarized in Figure 1-a and Table S1 (supplementary material). X-Ray Diffraction (XRD) pattern (Figure S1 of supplementary material) revealed the presence of a sub-stoichiometric spinel structure of iron oxide nanoparticles with a lattice parameter of $8.362 \pm 0.002 \AA$. The crystallite size, determined by XRD ( $\mathrm{d}_{\mathrm{XRD}}$ ) was estimated to $8.1 \pm 0.2 \mathrm{~nm}$, which was in accordance with transmission electronic microscopy (TEM) observations (Figure 1-b) giving a TEM diameter of $8.9 \pm 2.0 \mathrm{~nm}$. TEM pictures of functionalized SPIONs (Figure 1-b) show a good dispersion correlated to the hydrodynamic diameters described below. The specific surface area calculated by the BET method was $110 \pm 1 \mathrm{~m}^{2} / \mathrm{g}$. The naked SPIONs suspension was stable at acidic $\mathrm{pH}$ and unstable at neutral one. The isoelectric point of naked SPIONs was about 7 (Figure S2-a). The number-weighted hydrodynamic diameter at $\mathrm{pH} 3$ was $23 \pm 6 \mathrm{~nm}$ (Figure S2-a and b). At pH 7 and due to the isoelectric point, the hydrodynamic diameters weighted either in number or in intensity is around $2400 \mathrm{~nm}$ proving the agglomeration of these nanoparticles under these conditions (Table S1). The surface modified nanoparticles revealed a negative zeta potential, around $-20 \mathrm{mV}$ at physiological $\mathrm{pH}$ and their hydrodynamic diameters were around $72 \pm 32 \mathrm{~nm}$ in intensity with 2 populations centered at 44 and $31 \mathrm{~nm}$ and about $25 \pm 8 \mathrm{~nm}$ in number (Figure S2-a and b). The numberweighted value of the hydrodynamic diameter is close to the value of the naked SPIONs under stable conditions ( $\mathrm{pH} 3$ ) proving the efficient grafting of the PEG and that the functionalization of the naked SPIONs with $\mathrm{mPEG}_{2000}-\mathrm{Si}$ and RITC-Si stabilized them under physiological conditions. In addition to a fluorescence detection, Rhodamine seems to provide negative charges to the SPIONs at pH 7. TGA analyses of naked SPIONs and fSPIONs showed a weight loss of $3 \%$ and $62 \%$ respectively (Figure S3-a). This latter percentage allows estimating the grafting rate of PEG 
to $3.5 \mathrm{PEG}_{2000} / \mathrm{nm}^{2}$ of nanoparticle. UV-visible analyses (Figure S3-b) showed almost 0.044 molecules of RITC-Si/nm ${ }^{2}$ of fSPIONs. The detailed calculation are given in supplementary information and on the table S2.

\begin{tabular}{|c|c|c|}
\hline a) & \multicolumn{2}{|c|}{ Main characterizations of fSPIONs } \\
\hline \multirow{7}{*}{ 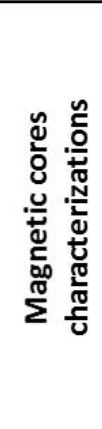 } & XRD diameter (nm) & $8.1 \pm 0.2$ \\
\hline & TEM diameter $(\mathrm{nm})$ & $8.9 \pm 2.0$ \\
\hline & BET surface $\left(\mathrm{m}^{2} / \mathrm{g}\right)$ & $110 \pm 1$ \\
\hline & $\mathrm{dH}$ in number at $\mathrm{pH} \mathbf{3}(\mathrm{nm})$ & $23 \pm 6$ \\
\hline & Iso-electric point & $\mathrm{pH} 7$ \\
\hline & Zeta potential at pH $7(\mathrm{mV})$ & 0 \\
\hline & Weight loss & $3 \%$ \\
\hline \multirow{6}{*}{ 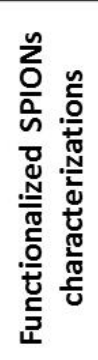 } & $\mathrm{dH}$ in number at $\mathrm{pH} 7(\mathrm{~nm})$ & $25 \pm 8$ \\
\hline & Iso-electric point & $<\mathrm{pH} 3$ \\
\hline & Zeta potential at $\mathrm{pH} 7(\mathrm{mV})$ & -20 \\
\hline & Weight loss & $62 \%$ \\
\hline & $\mathrm{mPEG}-\mathrm{Si} / \mathrm{nm}^{2}$ & 3.5 \\
\hline & RITC-Si/nm² & 0.044 \\
\hline
\end{tabular}

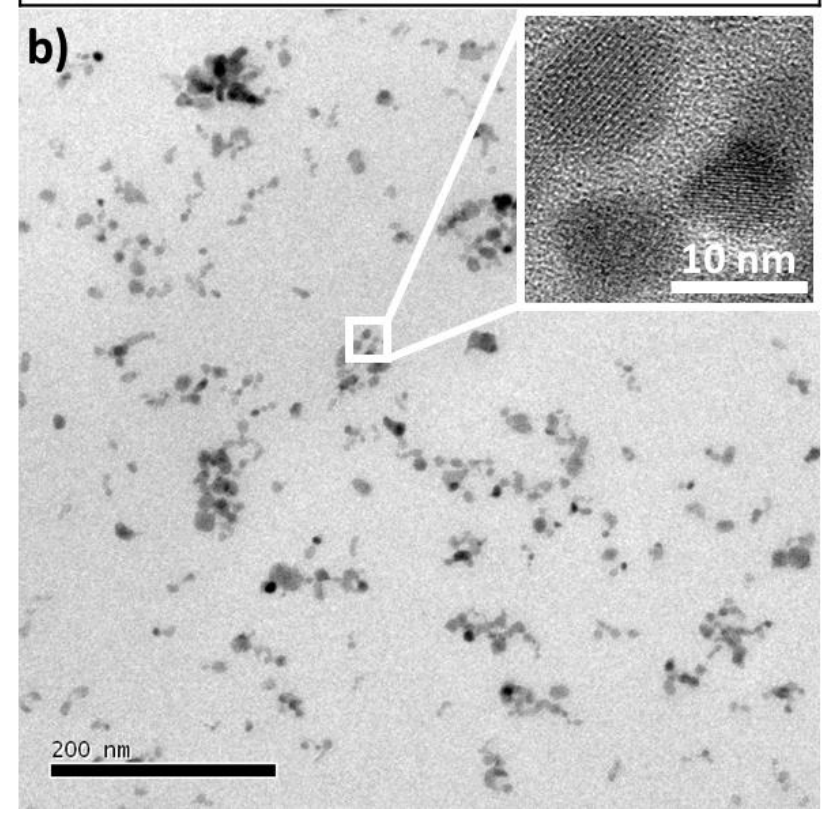

Figure 1: a) Summary of the characterizations of naked and functionalized SPIONs (XRD: X-Ray diffraction; Transmission electron microscopy (TEM); dH: hydrodynamic diameter); b) TEM pictures of functionalized SPIONs with a zoom section on the top right corner. 


\section{Internalization of fSPIONs: influence on morphology}

Morphological changes of cells in the presence of nanoparticles were evaluated by phase contrast microscopy and flow cytometry. This parameter was studied since the cells may undergo morphological changes in the presence of potentially cytotoxic agents. Phase contrast microscopy of treated cells (Figure S4 of supplementary material) shows no change in their morphology after $6 \mathrm{~h}$ of incubation, at different concentrations of SPIONs. As more floating cells were observed for the highest concentrations ( 50 and $100 \mu \mathrm{g}_{\mathrm{Fe}} / \mathrm{mL}$ ), this data suggests that the interaction of fSPIONs with $158 \mathrm{~N}$ cells could modify cell adhesion [33].

As the cells-nanoparticles interaction can lead to cytotoxic effects, including cells death, complementary methods of cell biology and biochemistry (flow cytometry, confocal microscopy and transmission electron microscopy) were further used to precise the possible cytotoxicity of fSPIONs. By flow cytometry, the cell interaction and/or internalization of nanoparticles $(1,5,10$, 50 and $100 \mu \mathrm{g}_{\mathrm{Fe}} / \mathrm{mL}, 6 \mathrm{~h}$ ) were measured with the forward and side scatters (FSC and SSC) and RITC fluorescence values (Figure 2). Confocal microscopy was also used to evaluate the accumulation of fSPIONs $\left(50 \mu \mathrm{g}_{\mathrm{Fe}} / \mathrm{mL}, 2,4\right.$ and $\left.6 \mathrm{~h}\right)$ in the cytoplasm. The MFI increased with nanoparticle concentration proving the interaction and/or internalization of nanoparticles with cells (Figure 2-a and b), whereas FSC and SSC were not modified comparatively to untreated cells, (Figure 2-b). 

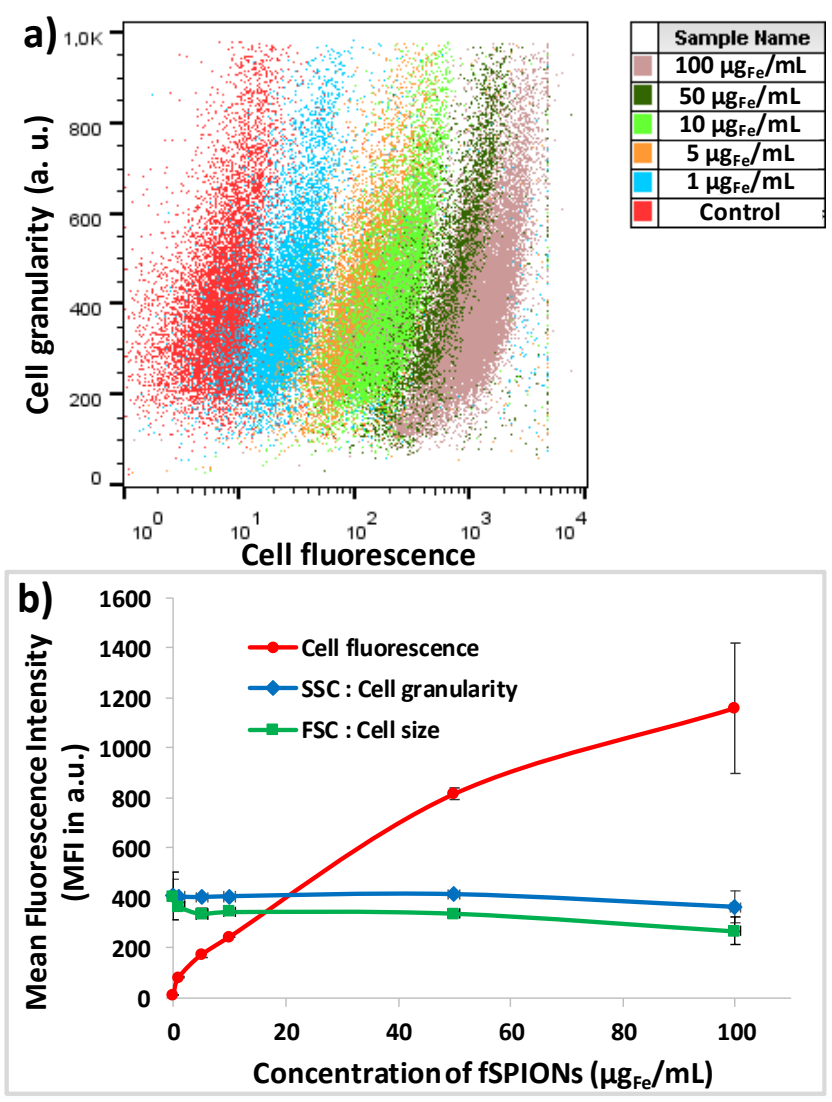

Figure 2: Flow cytometric analysis of fSPIONs used at different concentrations after $6 \mathrm{~h}$ of incubation: a) Flow cytometric measurement of RITC fluorescence intensity versus side scatter (SSC) on 158N cells; b) Measurement of MFI (related to RITC fluorescence intensity), FSC and SSC. Data are expressed in arbitrary units (a.u.). Number of experiments $n=3$

The assessment of the nanoparticles internalization into cells is an important step to evaluate their toxicity. The internalization of fSPIONs $\left(50 \mu \mathrm{g}_{\mathrm{Fe}} / \mathrm{mL}\right)$ by $158 \mathrm{~N}$ cells was confirmed by confocal microscopy based on observations realized after 2, 4 and $6 \mathrm{~h}$ of incubation with the nanoparticles. Indeed, the resulting images shown in Figure 3 which are stack of images superimposed with images obtained by phase contrast microscopy clearly reveal the presence of fSPIONs giving a red fluorescence, in the cytoplasm. Whatever the conditions of treatment, the cells are adherent, and have the same shape than the untreated cells, supporting again the absence of cytotoxic effect (Figure 3). 


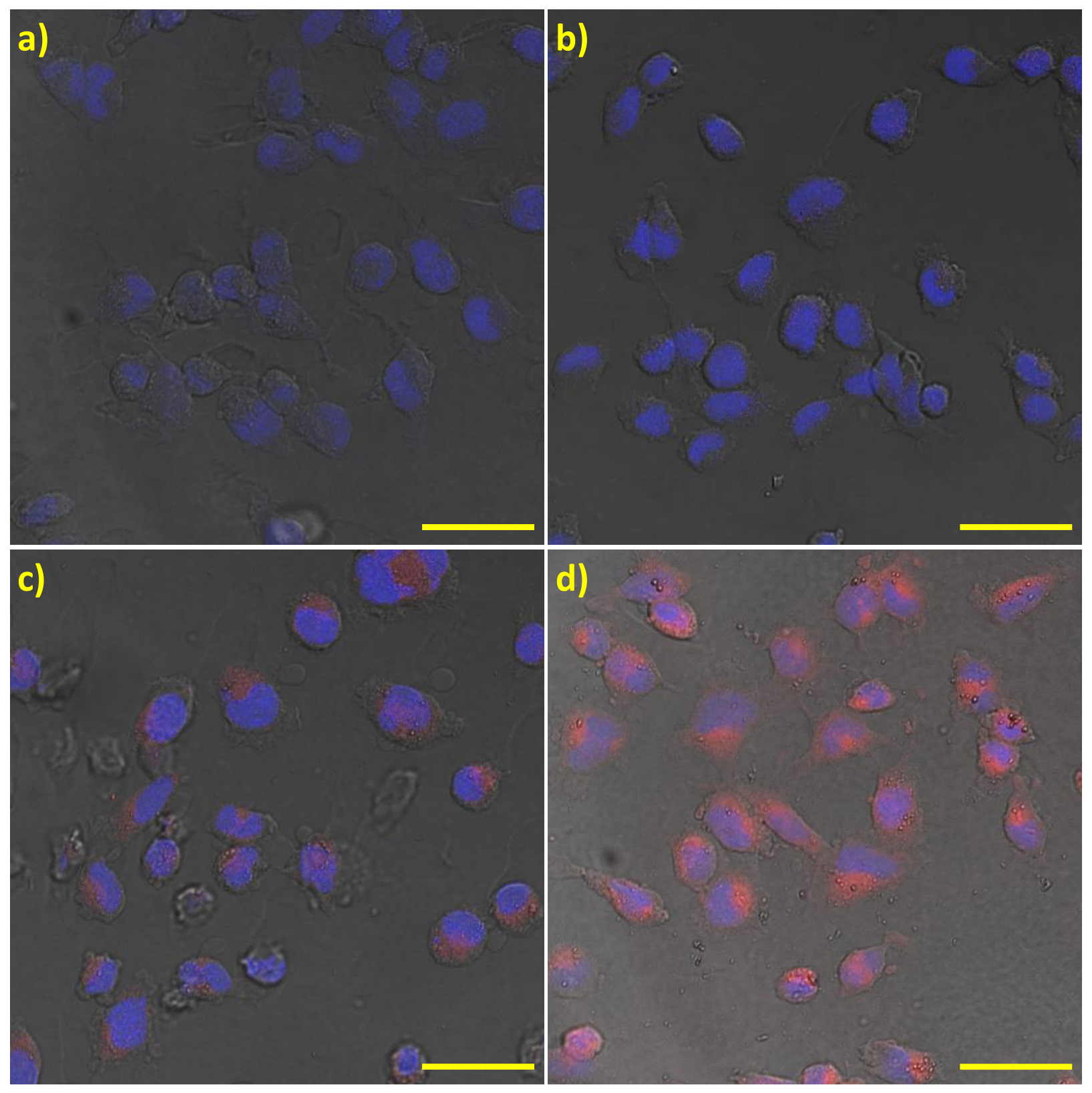

Figure 3: Confocal microscopy combining phase contrast and fluorescence on $158 \mathrm{~N}$ cells incubated for $6 \mathrm{~h}$ with fSPIONs used at different concentrations: a) control; b) $1 \mu \mathrm{g}_{\mathrm{Fe}} / \mathrm{mL}$; c) $10 \mu \mathrm{g}_{\mathrm{Fe}} / \mathrm{mL}$; d) 50 $\mu \mathrm{g}_{\mathrm{Fe}} / \mathrm{mL}$. Blue: nuclei stained with Hoechst 33342 and red: fSPIONs (RITC fluorescence). Scale bar: $25 \mu \mathrm{m}$

The nanoparticle internalization was further confirmed by TEM images of cells incubated with fSPIONs $\left(50 \mu \mathrm{g}_{\mathrm{Fe}} / \mathrm{mL}\right)$ (TEM images are given in Figure S5 of supplementary material). After $6 \mathrm{~h}$ of incubation, vesicular structures, evocating lysosomes and/or endosomes were observed [34]. Inside the cells, as the vesicles containing SPIONs have sizes in the ranges of 50-100 nm, these observations evocate an accumulation of nanoparticles via endocytosis. 


\section{Quantification of fSPIONs positive cells with the Perls staining method}

Perls staining method revealed a dose-dependent increase in the percentage of fSPIONs positive cells. For 1, 5, 10, 50 and $100 \mu \mathrm{g}_{\mathrm{Fe}} / \mathrm{mL}$ of fSPIONs, the percentage of fSPIONs positive cells were $39,53,60,75$ and 79, respectively (Figure 4). Moreover, 158N cells previously treated for $24 \mathrm{~h}$ with various concentrations of fSPIONs $\left(1,10\right.$ and $\left.100 \mu \mathrm{g}_{\mathrm{Fe}} / \mathrm{mL}\right)$ were collected by trypsinization, and the intracellular accumulation of iron was determined by atomic absorption spectrometry (Figure 4). The results show that the intracellular iron concentration increases with the concentration of nanoparticles. The intracellular iron content was $0.4,1.3,5.3$ and $28.2 \mu \mathrm{g}_{\mathrm{Fe}} / \mathrm{mL}$ for $0,1,10$ and $100 \mu \mathrm{g}_{\mathrm{F}} / \mathrm{mL}$ of fSPIONs, respectively. These values measured by ICP correspond to $90 \%$ ([1.3-0.4]/1), $49 \%$ and $28 \%$ of the dose injected to the $158 \mathrm{~N}$ cells.

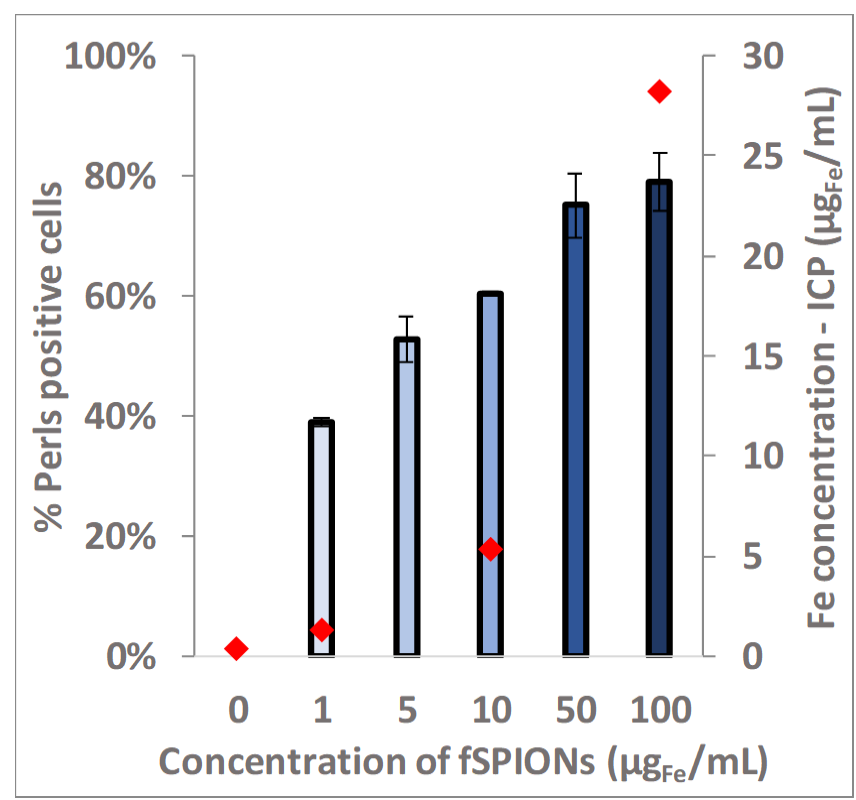

Figure 4: Percentages of Perls positive 158N cells and iron concentration in $158 \mathrm{~N}$ cells incubated for $24 \mathrm{~h}$ with different fSPIONs concentrations (red diamonds). Number of experiments $n=3$

\section{Magnetic cell sorting of fSPIONs positive cells}

The fSPIONs positive cells were recovered by using a strong magnetic field generated by a magnet (EasySep, ref: 18 000, StemCell Technologies, Grenoble, France). To this end, after cells incubation with fSPIONs $\left(50 \mu \mathrm{g}_{\mathrm{Fe}} / \mathrm{mL}, 24 \mathrm{~h}\right), 158 \mathrm{~N}$ cells were trypsinized and re-suspended in $4 \mathrm{~mL}$ of PBS. In those conditions, $85 \pm 2 \%$ of the cells retained by the magnet were stained in blue 
with the Perls staining procedure. In the supernatant, $32 \pm 1 \%$ of cells were stained with the Perls staining procedure (Figure S6). This data proves that a small amount of internalized SPIONs is sufficient to make cells sensitive to an external magnetic field. These results demonstrate that it is possible to manipulate fSPIONs positive cells subjected to a magnetic field; this opens different perspectives of work in vitro and in vivo [15].

\section{Cell viability}

Cell viability was measured by trypan blue exclusion assay with a Malassez hematocytometer and by flow cytometry after staining with Sytox green. Cell counting using trypan blue neither revealed a reduction of cell growth nor an increase of dead cells after $24 \mathrm{~h}$ of culture in the presence of nanoparticles compared to control cells (Figure 5-a). These data agree with those obtained with Sytox Green (Figure 5-b). This data also supports that the loss of cell adhesion observed by phase contrast microscopy is not due to cell death induction.
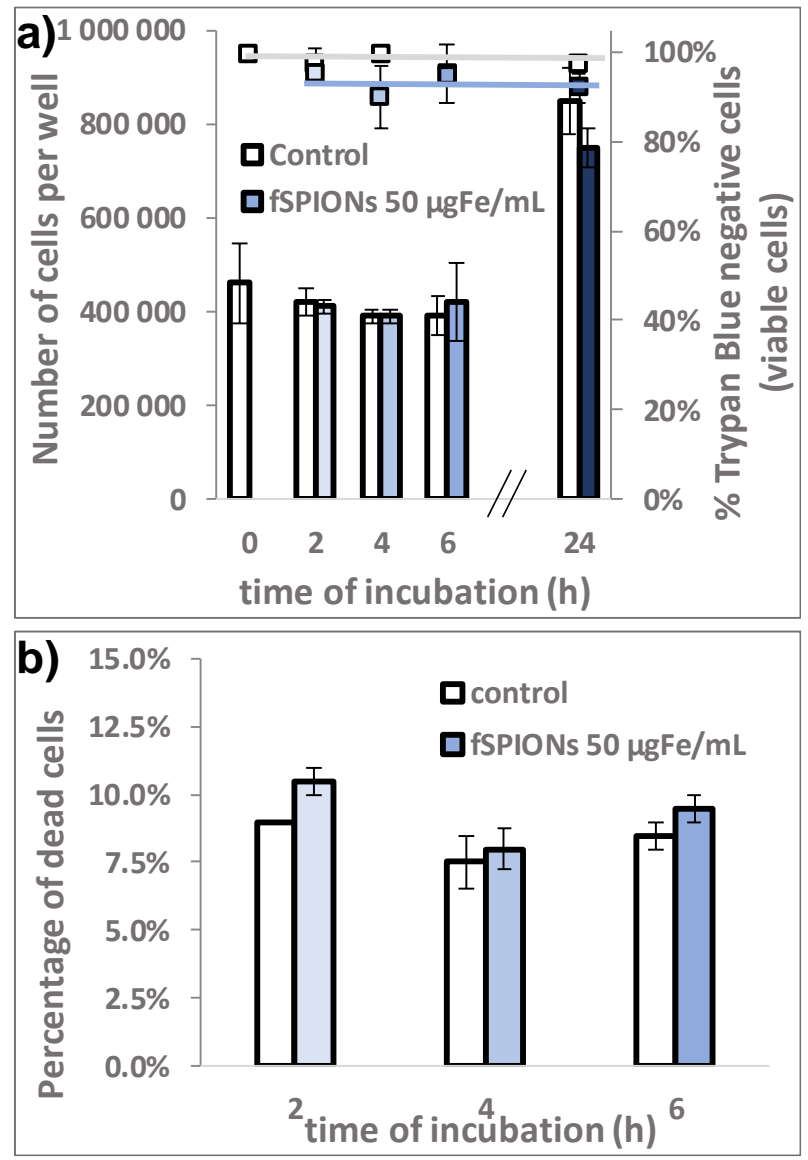
Figure 5: Incubation with fSPIONs at $50 \mu \mathrm{g}_{\mathrm{Fe}} / \mathrm{mL}$ for different times: a) (Histograms) total number of $158 \mathrm{~N}$ cells per Petri dish after incubation and (Squares) percentages of viable cells after incubation; b) Percentages of dead cells after incubation. Number of experiments $n=3$. No significant differences were observed between control and fSPIONs-treated cells.

\section{Oxidative stress}

The ability of nanoparticles to trigger oxidative stress on $158 \mathrm{~N}$ cells was evaluated by measuring the intracellular ROS production by $\mathrm{H}_{2}$ DCF-DA assay (158N cells treated for 2,4 , and $6 \mathrm{~h}$ with $100 \mu \mathrm{g}_{\mathrm{Fe}} / \mathrm{mL}$ ). The intracellular GSH level was also evaluated, using flow cytometry, by mean fluorescence intensity after staining with monochlorobimane (158N cells treated for $6 \mathrm{~h}$ with 50 and $\left.100 \mu \mathrm{g}_{\mathrm{Fe}} / \mathrm{mL}\right)$. Comparatively to control cells, no marked increase in ROS production was detected with the $\mathrm{H}_{2}$ DCF-DA assay (Figure 6-a) whereas in the presence of positive controls (7-ketocholesterol $(7 \mathrm{KC})$ and hydrogen peroxide $\left(\mathrm{H}_{2} \mathrm{O}_{2}\right)$, strong fluorescence intensities were found (Figure S7 in supplementary materials). In addition, no significant change in the GSH level was observed for the treated cells compared to the control. However, as expected, a significant decrease of intracellular GSH level was observed for cells treated with diamide, used for the positive control. The GSH contents in fSPIONs treated cells and in the control were almost similar (Figure 6-b). 

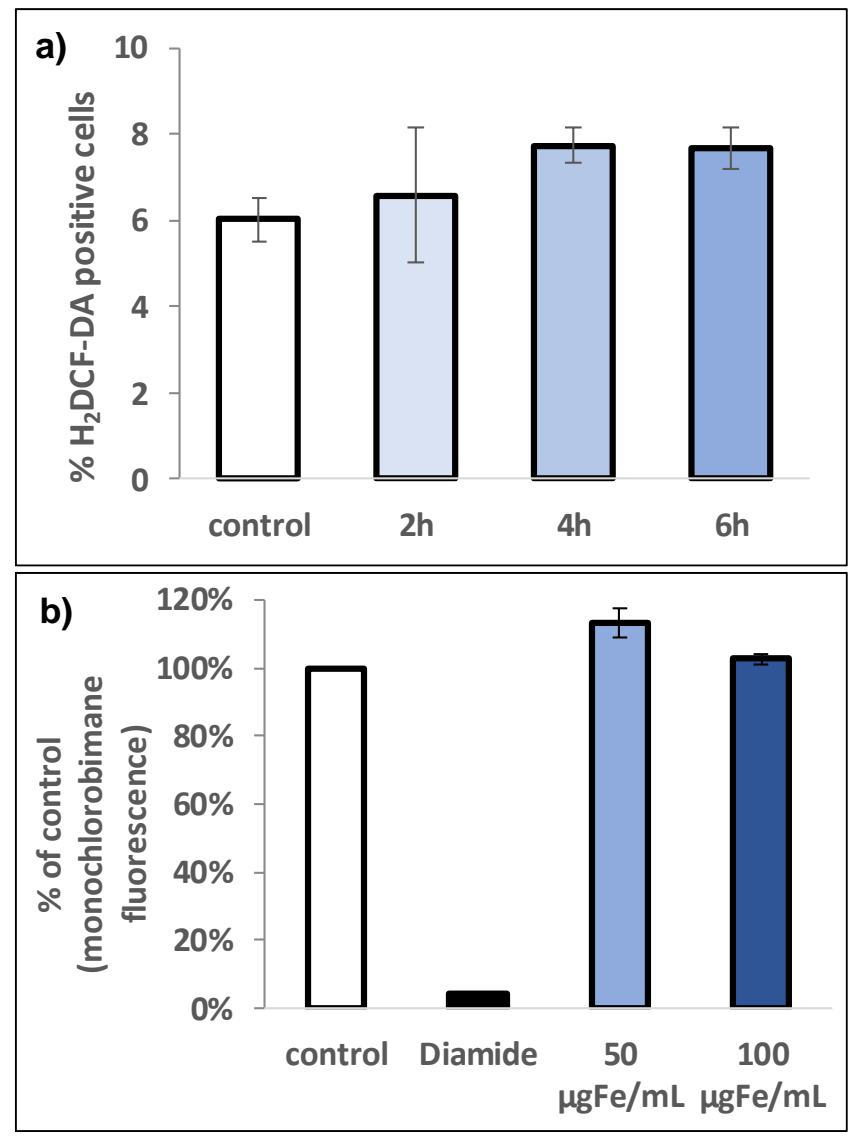

Figure 6: a) Flow cytometric quantification of the percentage of H2DCF-DA positive 158N cells after incubation with $100 \mu \mathrm{g}_{\mathrm{Fe}} / \mathrm{mL}$ fSPIONs at different times; b) Flow cytometric quantification of reduced glutathione (GSH), data shown are evaluated in \% control [mean fluorescence intensity of assay/mean fluorescence intensity of control]). The control corresponds to untreated cells, and the assays to cells either incubated with fSPIONs used at 50 or $100 \mu \mathrm{g}_{\mathrm{Fe}} / \mathrm{mL}$ or with $0.5 \mathrm{mM}$ diamide (positive control used to decrease the intracellular level of GSH). Number of experiments $n=3$. No significant differences were observed between control and fSPIONs-treated cells.

\section{Inflammatory response}

The level of IL-1 $\beta$ and IL-6 in the culture medium were assessed by ELISA to measure inflammatory cytokine secretion under treatment with fSPIONs $\left(100 \mu \mathrm{g}_{\mathrm{Fe}} / \mathrm{mL}\right)$. The measurement was carried out after 2, 4, 6 and $24 \mathrm{~h}$ of incubation. Figure 7 shows no significant changes in the IL-1 $\beta$ and IL-6 levels at the different treatment times. 


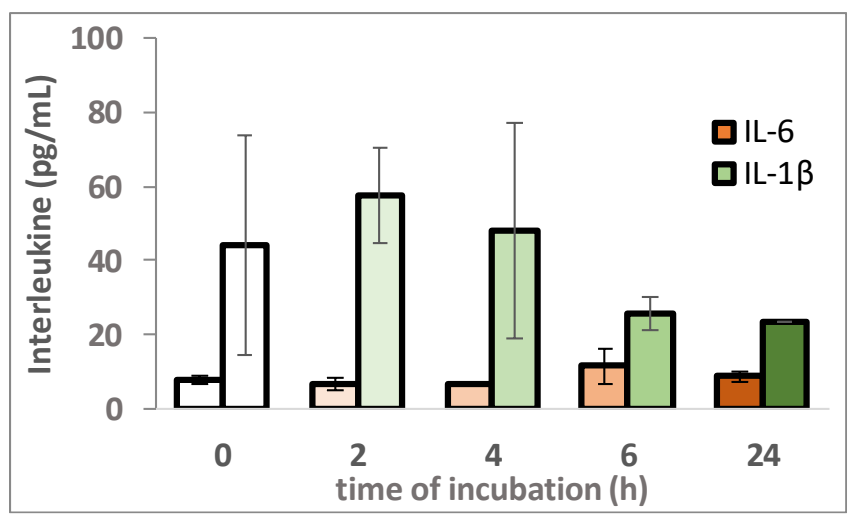

Figure 7: Concentrations of IL-6 and IL-1 $\beta$ in the culture medium of $158 \mathrm{~N}$ cells incubated with $100 \mu \mathrm{g}_{\mathrm{Fe}} / \mathrm{mL}$ of fSPIONs for different times. Number of experiments $\mathbf{n}=3$. No significant differences were observed between control and fSPIONs-treated cells.

\section{Discussion}

The ability of iron oxide nanoparticles to cross the BBB makes them an outstanding material for drug delivery application across the Central Nervous System (CNS). In the present study, the fSPIONs - 158N cells interaction has been studied in details, prior to exploiting them for biomedical applications in the CNS. It has been previously reported that the fSPIONs do not cause cytotoxicity in nerve cells up to a concentration of $100 \mu \mathrm{g}_{\mathrm{Fe}} / \mathrm{mL}$. This concentration range is consdiered as safe with regard to cells viability [35]. However, the cytotoxicity could depend on the type of brain cells: indeed, no relevant toxicity was obtained for neurons and astrocytes [36], whereas a toxic effect was observed for microglial cells [37]. In the present study interaction of in-house synthesized SPIONs, functionalized with Rhodamine and PEG were studied with regard to its biomedical application potential and biocompatibility.

SPIONs which have been functionalized with polymers $\left(\mathrm{mPEG}_{2000}-\mathrm{Si}\right)$ and fluorophores (RITC-Si revealed the presence of PEG and RITC by TGA and UV-visible analyses. In addition, fSPIONs have a dispersion $(8.9 \pm 2.0 \mathrm{~nm}$ observed in TEM) and a hydrodynamic size (around $30 \mathrm{~nm}$ ) compatible with biological medium requirements and demonstrating the stabilizing effect of $\mathrm{mPEG}_{2000}-\mathrm{Si}$ on the nanoparticle's surface. Despite the low amount of RITC-Si per nanoparticle (0.044 RITC-Si/nm²), its presence nevertheless changed the zeta potential at $\mathrm{pH} 7$ because the $\mathrm{mPEG}_{2000}-\mathrm{Si}$ is known to be a neutral polymer. The zeta potential is shifted from $\mathrm{ca} .0 \mathrm{mV}$ for 
naked SPIONs to $-20 \mathrm{mV}$ once functionalized. In addition to the UV-visible measurements, this change in zeta potential could prove the presence of RITC on fSPIONs surface.

To study the cellular accumulation and retention of the fSPIONs, the fluorescence was measured in vitro. The results indicate that fSPIONs were still fluorescent even after $24 \mathrm{~h}$ of incubation. The increased photostability of the conjugated fluorophore compared to free fluorophores has been previously reported [12]. Fluorescence observed for such a long duration in the present study suggest the fSPIONs accumulation and retention in the cells for the measured duration. In addition, such a longer photostability hints to the potential of fSPIONs as a cell paint. The correlation between the fluorescence and Perls measurements demonstrates the actual grafting of RITC-Si on SPIONs. fSPIONs exposure at $1 \mu \mathrm{g}_{\mathrm{Fe}} / \mathrm{mL}$ concentration did not impart fluorescence to the cells despite the fact that around $40 \%$ cells stained positive in Perl staining. At this particular concentration, the number of particle received per cell is probably not enough to impart a detectable fluorescence by microscope. However, the cells exhibited a dose dependent response with regard to fluorescence property. These results agree with the study of M. Abdollah et al. [38] and D. Berndt et al. [39] who found that cellular uptake of iron oxide increases in a dose-dependent manner. Cell morphology was not altered in any of the fSPIONs concentration used in the present study. Interestingly, there observed a marked reduction in adherent cell density at highest concentrations used (50 and $100 \mu \mathrm{gFe} / \mathrm{mL}$ ). This finding indicate the influence of fSPIONs on the cells adhesion properties of the cells [33].

The amount of nanoparticles interacting with $158 \mathrm{~N}$ cells was measured both by Perls staining and by ICP (measuring iron content in cells), to understand the dosimetry and kinetics of fSPIONs in vitro. At the dose of $1 \mu \mathrm{g}_{\mathrm{Fe}} / \mathrm{mL}$ around $40 \%$ of cells stained positive for fSPION in Perls staining which constitute about $90 \%$ of the injected dose as quantified by ICP. On the other hand, only $28 \%$ of the injected dose were sufficient to stain $80 \%$ of the cells in $100 \mu \mathrm{g}_{\mathrm{Fe}} / \mathrm{mL}$ dosage. This finding is noteworthy as the particles uptake was not under particle concentration alone. The uptake is seemingly influenced by some limiting factor. Here the limiting factor is most likely to be the total cell surface area available for particle uptake. At higher concentrations cells surface might get saturated there by preventing further transport of nanoparticle across the membrane. The present study shows that after a certain concentration $\left(50 \mu \mathrm{g}_{\mathrm{Fe}} / \mathrm{mL}\right)$ cells reaches a plateau beyond which no fSPION uptake is possible by $158 \mathrm{~N}$ cells. 
One of the greatest advantage of SPION with regard to biomedical application is their ability to respond to external magnetic field. In the present study magnetic separation potency of the nanoparticles and total number of cells that could be separated using a particular concentration of nanoparticles were evaluated in presence of an external magnetic field. In our study, cells incubated with nanoparticles were sensitive to the external magnetic source. $85 \%$ of cells trapped by the magnet were positive to Perls reactant that was $10 \%$ higher than what was observed in the absence of the magnetic field. However, despite being unresponsive to the magnetic field around $30 \%$ of the unseparated cells were positive for Perl staining. It has been reported that- the efficiency of the magnetic cell -depends on different factors including the amount of magnetic particles per cell [40]. In accordance with these findings, low quantity of fSPIONs in the $158 \mathrm{~N}$ cells would not allow their magnetic separation. A more detailed study is required to find out the minimum concentration of fSPIONs required for an effective magnetic separation.

Cytotoxic potential of fSPIONs were evaluated using trypan blue exclusion assay and Sytox green assay. Both these assays independently indicated no loss of cell viability for fSPIONs. This study further confirms the above observation where fSPIONs influenced the cell adhesion properties of the cells. These results indicate that the cells floating in the culture medium at high concentrations of fSPIONs is still retain its viability. Even though loss of adhesion is a disadvantage regard to biomedical application, the desirable properties of fSPIONs can still be achieved effectively by lower concentrations.

The toxicity of iron oxide nanoparticles is mainly attributed to its ability to produce [41]. It is difficult to measure the oxidative stress in vitro as the ROS is short lived, and is influenced by a number of factors like stability of nanoparticle, development of protein corona, and nature of the cells. These factors often influenec assay results [42]. So, it is very important to measure the oxidative stress by different complementary methods. In the present study, effect of fSPIONs on oxidative stress was assessed by measuring the intracellular ROS and reduced glutathione (GSH) levels. Interestingly, ROS measurement and intracellular GSH levels measured for fSPIONs did not show any significant effect when compared to control cells. So, it is has to be assumed that at 6h of incubation, nanoparticles (50 and $100 \mu \mathrm{g}_{\mathrm{Fe}} / \mathrm{mL}$ ) do not induce ROS-mediated toxicity in oligodendrocyte cells. According to T. Coccini et al., nature of the cells influeneces the nanoparticle mediated cytoxicity [43]. Petters et al. have attributed the microglial toxicity of iron 
oxide nanoparticle to its lysosomal dissolution and ROS generation [44]. Since the dissolved iron can mediate ROS production via Fenton reaction, in the present study, it can be claimed that the nanoparticles remain stable inside the cell system. This stability might be due to the intact coating even after $24 \mathrm{~h}$ or due to of the lysosomal escape of nanoparticles. This result agrees with that obtained by M. Mahmoudi et al. who proved that nanoparticles toxicity is related to polyvinyl alcohol (PVA)/ SPIONs ratio. Indeed, they observed that nanoparticles biocompatibility can be enhanced by increasing this ratio [45].

IL-1 $\beta$ is an interleukin that plays an important role in inflammatory responses and hypersensitivity reactions in the CNS. IL-6 is also a pro-inflammatory cytokine. However, cytoprotective effects of IL-6 have been reported by Pizzi et al. in oligodendrocytes [46]. On the other hand, the same interleukin is involved in inflammation following brain injury [47]. Our results show no change in the IL-1 $\beta$ or IL- 6 secretion even after $24 \mathrm{~h}$ of incubation. These results proved that PEG prevent an increase of cytokine secretion compared to other polymer coatings such as polyvinyl alcohol (PVA) [48].

\section{Conclusion}

As a conclusion, we quantified the interaction between pegylated fluorescent iron oxide nanoparticles (fSPIONs) with $158 \mathrm{~N}$ murine oligodendrocytes. The internalization of fSPIONs into cells was evaluated by several complementary methods: phase contrast and confocal fluorescence microscopy, flow cytometry (measurement of side scatters: FSC and SSC, and mean fluorescence intensity (MFI)), TEM observations and ICP. A dose-dependent accumulation of nanoparticles in $158 \mathrm{~N}$ cells was observed by flow cytometry and confocal fluorescence microcopy as well as by iron quantification with Perls staining. Cells incubated with fSPIONs can be isolated thanks to a magnet. Interestingly, there was no influence of nanoparticles on cell growth and cell death. In addition, the iron oxide nanoparticles did not show any effect on ROS production. Furthermore, the nanoparticles do not increase the secretion of inflammatory cytokines. Thus, based on different cytotoxic criteria no side effects were observed with our fSPIONs on oligodendrocytes supporting that these nanoparticles can be consider for further applications in humans. 


\section{Acknowledgements and funding}

This work was supported by grants from: Université de Bourgogne (Dijon, France) and Région Bourgogne (PARI 2012-2013: contrat d'étude n²009-9201CPERO2S410). The authors are indebted to the following plateforms: Welience for atomic absorption spectrometry (Myriam Laly and Elodie Noirot); Plateforme DImaCell, INRA, Univ. Bourgogne Franche-Comté, (Dr Jeannine Lherminier, Mr. Benoît Gasquet).

\section{References}

[1] L. Maurizi, F. Bouyer, J. Paris, F. Demoisson, L. Saviot, N. Millot, One step continuous hydrothermal synthesis of very fine stabilized superparamagnetic nanoparticles of magnetite, Chemical Communications. 47 (2011) 11706-11708.

[2] C. Chambon, O. Clement, A. Le Blanche, E. Schouman-Claeys, G. Frija, Superparamagnetic iron oxides as positive MR contrast agents: in vitro and in vivo evidence, Magn Reson Imaging. 11 (1993) 509-519.

[3] G. Thomas, F. Demoisson, R. Chassagnon, E. Popova, N. Millot, One-step continuous synthesis of functionalized magnetite nanoflowers, Nanotechnology. 27 (2016) 135604. doi:10.1088/0957-4484/27/13/135604.

[4] A.K. Gupta, M. Gupta, Synthesis and surface engineering of iron oxide nanoparticles for biomedical applications, Biomaterials. $26 \quad$ (2005) 3995-4021. doi:10.1016/j.biomaterials.2004.10.012.

[5] J.M. Perez, L. Josephson, R. Weissleder, Use of magnetic nanoparticles as nanosensors to probe for molecular interactions, Chembiochem. 5 (2004) 261-264. doi:10.1002/cbic.200300730.

[6] C. Sun, R. Sze, M.Q. Zhang, Folic acid-PEG conjugated superparamagnetic nanoparticles for targeted cellular uptake and detection by MRI, Journal of Biomedical Materials Research Part A. 78A (2006) 550-557.

[7] R. Di Corato, N.C. Bigall, A. Ragusa, D. Dorfs, A. Genovese, R. Marotta, L. Manna, T. Pellegrino, Multifunctional Nanobeads Based on Quantum Dots and Magnetic Nanoparticles: Synthesis and Cancer Cell Targeting and Sorting, ACS Nano. 5 (2011) 1109-1121. doi: $10.1021 / \mathrm{nn} 102761 \mathrm{t}$.

[8] A. Tanimoto, S. Kuribayashi, Application of superparamagnetic iron oxide to imaging of hepatocellular carcinoma, Eur J Radiol. 58 (2006) 200-216. doi:10.1016/j.ejrad.2005.11.040.

[9] Y.-W. Huang, M. Cambre, H.-J. Lee, The Toxicity of Nanoparticles Depends on Multiple Molecular and Physicochemical Mechanisms, Int J Mol Sci. 18 (2017). doi:10.3390/ijms18122702.

[10] N. Lewinski, V. Colvin, R. Drezek, Cytotoxicity of nanoparticles, Small. 4 (2008) 26-49. doi:10.1002/smll.200700595. 
[11] L. Maurizi, A.-L. Papa, L. Dumont, F. Bouyer, P. Walker, D. Vandroux, N. Millot, Influence of Surface Charge and Polymer Coating on Internalization and Biodistribution of Polyethylene Glycol-Modified Iron Oxide Nanoparticles, Journal of Biomedical Nanotechnology. 11 (2015) 126-136. doi:10.1166/jbn.2015.1996.

[12] P. Howes, M. Green, A. Bowers, D. Parker, G. Varma, M. Kallumadil, M. Hughes, A. Warley, A. Brain, R. Botnar, Magnetic Conjugated Polymer Nanoparticles as Bimodal Imaging Agents, J. Am. Chem. Soc. 132 (2010) 9833-9842. doi:10.1021/ja1031634.

[13] J. Boudon, J. Paris, Y. Bernhard, E. Popova, R.A. Decreau, N. Millot, Magneto-Optical Nanomaterial: a SPIO-Phthalocyanine Scaffold built Step-by-Step towards Bimodal Imaging, Chem. Commun. 49 (2013) 7394-7396. doi:10.1039/C3CC41898G.

[14] A. Huefner, W.-L. Kuan, R.A. Barker, S. Mahajan, Intracellular SERS Nanoprobes For Distinction Of Different Neuronal Cell Types, Nano Lett. 13 (2013) 2463-2470. doi: $10.1021 / \mathrm{nl} 400448 \mathrm{n}$.

[15] O. Veiseh, C. Sun, C. Fang, N. Bhattarai, J. Gunn, F. Kievit, K. Du, B. Pullar, D. Lee, R.G. Ellenbogen, J. Olson, M. Zhang, Specific Targeting of Brain Tumors with an Optical/Magnetic Resonance Imaging Nanoprobe across the Blood-Brain Barrier, Cancer Res. 69 (2009) 6200-6207. doi:10.1158/0008-5472.CAN-09-1157.

[16] S. Altamura, M.U. Muckenthaler, Iron toxicity in diseases of aging: Alzheimer's disease, Parkinson's disease and atherosclerosis, J. Alzheimers Dis. 16 (2009) 879-895. doi:10.3233/JAD-2009-1010.

[17] J.R. Connor, S.L. Menzies, Cellular management of iron in the brain, J. Neurol. Sci. 134 Suppl (1995) 33-44.

[18] N. Baumann, D. Pham-Dinh, Biology of oligodendrocyte and myelin in the mammalian central nervous system, Physiol. Rev. $81 \quad$ (2001) 871-927. doi:10.1152/physrev.2001.81.2.871.

[19] S.K. Thorburne, B.H. Juurlink, Low glutathione and high iron govern the susceptibility of oligodendroglial precursors to oxidative stress, J. Neurochem. 67 (1996) 1014-1022.

[20] L. Zecca, M.B.H. Youdim, P. Riederer, J.R. Connor, R.R. Crichton, Iron, brain ageing and neurodegenerative disorders, Nat. Rev. Neurosci. 5 (2004) 863-873. doi:10.1038/nrn1537.

[21] T. Nury, A. Zarrouk, A. Vejux, M. Doria, J.M. Riedinger, R. Delage-Mourroux, G. Lizard, Induction of oxiapoptophagy, a mixed mode of cell death associated with oxidative stress, apoptosis and autophagy, on 7-ketocholesterol-treated $158 \mathrm{~N}$ murine oligodendrocytes: impairment by $\alpha$-tocopherol, Biochem. Biophys. Res. Commun. 446 (2014) 714-719. doi:10.1016/j.bbrc.2013.11.081.

[22] A.C. Feutz, D. Pham-Dinh, B. Allinquant, M. Miehe, M.S. Ghandour, An immortalized jimpy oligodendrocyte cell line: defects in cell cycle and cAMP pathway, Glia. 34 (2001) 241-252.

[23] M.S. Ghandour, A.-C. Feutz, W. Jalabi, O. Taleb, D. Bessert, M. Cypher, L. Carlock, R.P. Skoff, Trafficking of PLP/DM20 and cAMP signaling in immortalized jimpy oligodendrocytes, Glia. 40 (2002) 300-311. doi:10.1002/glia.10122.

[24] M.C. Hohnholt, M. Geppert, R. Dringen, Treatment with iron oxide nanoparticles induces ferritin synthesis but not oxidative stress in oligodendroglial cells, Acta Biomater. 7 (2011) 3946-3954. doi:10.1016/j.actbio.2011.06.052.

[25] M.C. Hohnholt, R. Dringen, Iron-dependent formation of reactive oxygen species and glutathione depletion after accumulation of magnetic iron oxide nanoparticles by oligodendroglial cells, J Nanopart Res. 13 (2011) 6761-6774. doi:10.1007/s11051-011-05857. 
[26] S. Jo, K. Park, Surface modification using silanated poly(ethylene glycol)s, Biomaterials. 21 (2000) 605-616.

[27] H. Suzuki, T. Toyooka, Y. Ibuki, Simple and Easy Method to Evaluate Uptake Potential of Nanoparticles in Mammalian Cells Using a Flow Cytometric Light Scatter Analysis, Environ. Sci. Technol. 41 (2007) 3018-3024. doi:10.1021/es0625632.

[28] T. Nury, A. Zarrouk, J.J. Mackrill, M. Samadi, P. Durand, J.-M. Riedinger, M. Doria, A. Vejux, E. Limagne, D. Delmas, M. Prost, T. Moreau, M. Hammami, R. Delage-Mourroux, N.M. O'Brien, G. Lizard, Induction of oxiapoptophagy on 158N murine oligodendrocytes treated by 7-ketocholesterol-, 7 $\beta$-hydroxycholesterol-, or 24(S)-hydroxycholesterol: Protective effects of $\alpha$-tocopherol and docosahexaenoic acid (DHA; C22:6 n-3), Steroids. 99 (2015) 194-203. doi:10.1016/j.steroids.2015.02.003.

[29] A. Zarrouk, A. Vejux, T. Nury, H.I. El Hajj, M. Haddad, M. Cherkaoui-Malki, J.-M. Riedinger, M. Hammami, G. Lizard, Induction of Mitochondrial Changes Associated with Oxidative Stress on Very Long Chain Fatty Acids (C22:0, C24:0, or C26:0)-Treated Human Neuronal Cells (SK-NB-E), Oxid Med Cell Longev. 2012 (2012). doi:10.1155/2012/623257.

[30] W. Strober, Trypan blue exclusion test of cell viability, Curr Protoc Immunol. Appendix 3 (2001) Appendix 3B. doi:10.1002/0471142735.ima03bs21.

[31] E. Kahn, M. Baarine, S. Pelloux, J.-M. Riedinger, F. Frouin, Y. Tourneur, G. Lizard, Iron nanoparticles increase 7-ketocholesterol-induced cell death, inflammation, and oxidation on murine cardiac HL1-NB cells, Int J Nanomedicine. 5 (2010) 185-195.

[32] G. Lizard, S. Gueldry, O. Sordet, S. Monier, A. Athias, C. Miguet, G. Bessede, S. Lemaire, E. Solary, P. Gambert, Glutathione is implied in the control of 7-ketocholesterol-induced apoptosis, which is associated with radical oxygen species production, FASEB J. 12 (1998) 1651-1663.

[33] A.K. Gupta, A.S.G. Curtis, Lactoferrin and ceruloplasmin derivatized superparamagnetic iron oxide nanoparticles for targeting cell surface receptors, Biomaterials. 25 (2004) 3029-3040. doi:10.1016/j.biomaterials.2003.09.095.

[34] A.-L. Papa, L. Dumont, D. Vandroux, N. Millot, Titanate nanotubes: towards a novel and safer nanovector for cardiomyocytes, Nanotoxicology. $7 \quad$ (2012) 1131. doi:10.3109/17435390.2012.710661.

[35] S. Naqvi, M. Samim, M.Z. Abdin, F.J. Ahmed, A.N. Maitra, C.K. Prashant, A.K. Dinda, Concentration-dependent toxicity of iron oxide nanoparticles mediated by increased oxidative stress, Int. J. Nanomed. 5 (2010) 983-989. doi:10.2147/IJN.S13244.

[36] M.-C. Lamkowsky, M. Geppert, M.M. Schmidt, R. Dringen, Magnetic field-induced acceleration of the accumulation of magnetic iron oxide nanoparticles by cultured brain astrocytes, J. Biomed. Mater. Res. Part A. 100A (2012) 323-334. doi:10.1002/jbm.a.33263.

[37] E.M. Luther, C. Petters, F. Bulcke, A. Kaltz, K. Thiel, U. Bickmeyer, R. Dringen, Endocytotic uptake of iron oxide nanoparticles by cultured brain microglial cells, Acta Biomater. 9 (2013) 8454-8465. doi:10.1016/j.actbio.2013.05.022.

[38] M.R.A. Abdollah, T.J. Carter, C. Jones, T.L. Kalber, V. Rajkumar, B. Tolner, C. Gruettner, M. Zaw-Thin, J. Baguña Torres, M. Ellis, M. Robson, R.B. Pedley, P. Mulholland, R. T. M. de Rosales, K.A. Chester, Fucoidan Prolongs the Circulation Time of Dextran-Coated Iron Oxide Nanoparticles, ACS Nano. (2018). doi:10.1021/acsnano.7b06734.

[39] D. Berndt, J.M. Millward, J. Schnorr, M. Taupitz, V. Stangl, F. Paul, S. Wagner, J.T. Wuerfel, I. Sack, A. Ludwig, C. Infante-Duarte, Inflammation-induced brain endothelial activation leads to uptake of electrostatically stabilized iron oxide nanoparticles via sulfated 
glycosaminoglycans, Nanomed.-Nanotechnol. Biol. Med. 13 (2017) 1411-1421. doi:10.1016/j.nano.2017.01.010.

[40] K.E. McCloskey, J.J. Chalmers, M. Zborowski, Magnetic Cell Separation: Characterization of Magnetophoretic Mobility, Analytical Chemistry. 75 (2003) 6868-6874. doi:10.1021/ac034315j.

[41] M. Mahmoudi, S.E. Lohse, C.J. Murphy, A. Fathizadeh, A. Montazeri, K.S. Suslick, Variation of Protein Corona Composition of Gold Nanoparticles Following Plasmonic Heating, Nano Lett. 14 (2014) 6-12. doi:10.1021/nl403419e.

[42] M. Roesslein, C. Hirsch, J.-P. Kaiser, H.F. Krug, P. Wick, Comparability of in Vitro Tests for Bioactive Nanoparticles: A Common Assay to Detect Reactive Oxygen Species as an Example, International Journal of Molecular Sciences. 14 (2013) 24320-24337. doi:10.3390/ijms141224320.

[43] T. Coccini, F. Caloni, L.J. Ramirez Cando, U. De Simone, Cytotoxicity and proliferative capacity impairment induced on human brain cell cultures after short- and long-term exposure to magnetite nanoparticles, J. Appl. Toxicol. 37 (2017) 361-373. doi:10.1002/jat.3367.

[44] C. Petters, K. Thiel, R. Dringen, Lysosomal iron liberation is responsible for the vulnerability of brain microglial cells to iron oxide nanoparticles: comparison with neurons and astrocytes, Nanotoxicology. 10 (2016) 332-342. doi:10.3109/17435390.2015.1071445.

[45] M. Mahmoudi, A. Simchi, A.S. Milani, P. Stroeve, Cell toxicity of superparamagnetic iron oxide nanoparticles, Journal of Colloid and Interface Science. 336 (2009) 510-518. doi:10.1016/j.jcis.2009.04.046.

[46] M. Pizzi, I. Sarnico, F. Boroni, M. Benarese, M. Dreano, G. Garotta, A. Valerio, P. Spano, Prevention of neuron and oligodendrocyte degeneration by interleukin-6 (IL-6) and IL-6 receptor/IL-6 fusion protein in organotypic hippocampal slices, Mol. Cell. Neurosci. 25 (2004) 301-311. doi:10.1016/j.mcn.2003.10.022.

[47] H.Q. Yan, M.A. Banos, P. Herregodts, R. Hooghe, E.L. Hooghe-Peters, Expression of interleukin (IL)-1 beta, IL-6 and their respective receptors in the normal rat brain and after injury, Eur. J. Immunol. 22 (1992) 2963-2971. doi:10.1002/eji.1830221131.

[48] C. Strehl, T. Gaber, L. Maurizi, M. Hahne, R. Rauch, P. Hoff, T. Häupl, M. HofmannAmtenbrink, A.R. Poole, H. Hofmann, F. Buttgereit, Effects of PVA coated nanoparticles on human immune cells, Int J Nanomedicine. 10 (2015) 3429-3445. doi:10.2147/IJN.S75936. 


\section{Graphical abstract}

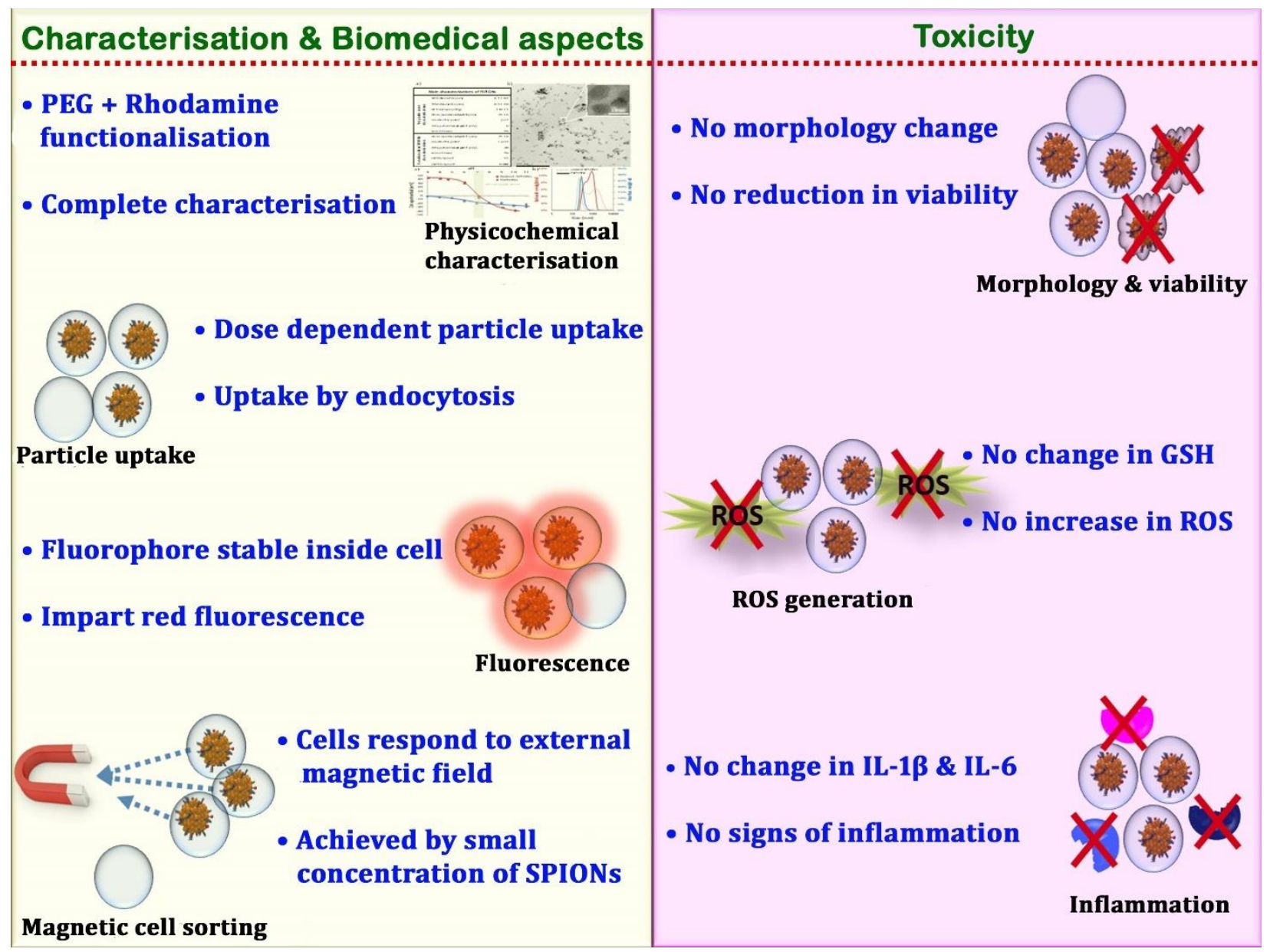

